\title{
The Development Directions of U-City Competitiveness Index
}

\author{
Kim, Kir"* Kwak, Su Jung** • Shin, Dong Bin***
}

要 旨

본 연구는 U-City 경쟁력의 개념 및 U-City 관련 지수의 연구동향을 파악하여 U-City 경쟁력 지수의 개발방향을 제 시하는데 목적이 있다. 이를 위해 먼저 정보화시대, 미래도시, U-City의 개념을 관련문헌을 토대로 파악하고, UCity 경쟁력의 개념을 제시하였다. 다음으로 U-City를 비롯한 미래도시 관련 지수의 연구동향을 파악하여 U-City 경쟁력 지수 개발에의 시사점을 도출하였다. 마지막으로 U-City 경쟁력지수 개발 절차와 각 단계에서의 유의점을 제시하였다. 연구결과 U-City 경쟁력은 거주민의 요구사항에 대한 신속한 대응 및 도시공간 관리의 효율성을 극대 화할 수 있는 ICT, U-City 인프라, U-City 서비스, U-City 관리 능력을 의미하며, 이를 측정하기 위해 평가체계의 마련, 평가지표의 선정, 표준화, 지표별 가중치 산정, 평가모형 설정의 개발절차가 필요한 것으로 파악되었다.

핵심용어 : U-City, 미래도시, 스마트시티, 도시경쟁력, U-City 경쟁력 지수

\begin{abstract}
This study ultimately aims to suggest directions for development of U-City Competitiveness Index through thorough analyses of U-City competitiveness concepts and previous research in U-City-related index. In an attempt to reach the aforementioned goals, the concept of U-City competitiveness is presented based on existing publications on informatization age, future city, and U-City. Next, insights on the development of U-City Competitiveness Index are provided via analysis of research on indices regarding U-City and future city. Finally, the process of developing UCity Competitiveness Index and cautionary comments for each developmental step has been provided. Based on the research results, U-City competitiveness refers to the ability to respond to demands of residents in a timely manner as well as to manage U-City, ICT, U-City infrastructure, and U-City services that maximizes the efficiency of urban space management. In order for proper assessment of these criteria, development of assessment tools, selection of indices, standardization, allocation of weight per index, and construction of assessment framework are required.

Keywords : U-City, future city, smart city, urban competitiveness, U-City Competitiveness Index
\end{abstract}

\section{Introduction}

\subsection{Background}

A U-City is a future city where ubiquitous technology is integrated into urban space (KRIHS, 2012). It is designed to efficiently manage a city by providing necessary information to its residents immediately upon request and provide the urban space plan to maximize convenience. Korea has developed $37 \mathrm{U}^{-}$ Cities since 2008. In addition, Korean government enacted law and guidelines about U-City such as 'Act on Ubiquitous City Construction,' 'Guidelines of Ubiquitous City Plan,' and 'Guidelines of Ubiquitous
City Infrastructure Management.'

Despite the efforts made by each local government to contribute to the smooth functioning of the U-City and to improve the quality of life of residents, there is no existing system that shows or evaluates the status of the U-City development. In addition, previous U-City plans had a tendency to focus on ideal situations although there are fundamental differences between research and the applicability of its results in real life (Kim et al., 2011). The existing U-City plan does not provide realistic measures for adequate evaluation of the city management after development.

2012년 1월 31일 접수, 2012년 2월 22일 채택

* Member·Research Fellow, Korea Research Institute for Human Settlements(kirlk@krihs.re.kr)

** Member - Assistant Research Fellow, Korea Research Institute for Human Settlements(sjkwak@krihs.re.kr)

*** Corresponding Author·Member·Professor, Anyang University(dbshin@anyang.ac.kr) 


\subsection{Purpose}

The U-City Competitiveness Index is designed to overcome the aforementioned limitations and it is hoped that the use of this index will make the evaluation of the competitiveness of the U-City more reasonable and objective in the long run. The purpose of this research is to provide the vision of U-City Competitiveness Index through analyses on future city-related indices. Thus, this study defines the concept of the U-City competitiveness based on the concepts of informatization, future city, and U-City. The indicators used in the existing future-city-related indices are considered as part of literature review. Based on the information presented, a plan for developing U-City Competitiveness Index is suggested.

\section{Concept of the U-City Competitiveness}

\subsection{Concept of the Informatization Era}

Informatization era refers to the trend or activity through which social economy is carried out where values are created centered on information. As the focus of industrial structure shifted from manufacturing-intensive to information-intensive industry, information is considered as the most important resource in the current society. Due to the widespread information-communication network, it has become possible to consummate efficient and creative lifestyle. Furthermore, a new form of society, called informatization era, which overcomes geographical and spatial limitation, has emerged. Remote medical care and telecommuting as well as virtual space, society, and nation are some of the features of the informatization era(Shin, 2011).

\subsection{Concept of the Future City}

U-City has been researched as a trend of future city. There are some other similar concepts of future city. Thus, this paragraph will explore the various concept of future city. Smart City and Intelligent City are widely-accepted terms that refer to similar concepts as the U-City used in Korea. There are slight differences, however, in definitions of Smart City and Intelligent City in discussions regarding the future city.

The term Smart City was interpreted as a new type of city where hard and soft infrastructures work harmoniously to enable all residents to use intellectual services(NIA, 2010). Here, hard infrastructure refers to the IT infrastructure capable of making self-recognition and self-improvement whereas soft infrastructure refers to IT and IT-related services that allow for enrichment in education, safety, and welfare of the residents. NIA(2010) especially noted that active participation and cooperation among government, industry and citizens that are essential for obtaining competence on soft infrastructure are at the core of any Smart City.

Vienna University of Technology(2007) identifies six characteristics of a Smart City in its project named 'Smart Cities: Ranking of European mediumsized Cities.' The six characteristics are: smart economy, smart mobility, smart environment, smart people, smart living, and smart governance. In the project, the Smart City is defined as that displays high performance with a vision aheadencompassing the aforementioned six characteristics. In addition, the Smart City is one that is built on the 'smart' combination of endowments and activities of self-decisive, independent and aware citizens.

Taipei Institute for Information Industry, also known as Taipei III(2010), defines the concept of Smart City as a city where it is constructed with a comprehensive ICT infrastructure to provide its residents interactive and integrated information and updates. It ultimately aims to enhance the quality of life of the residents, empower the industry in its entrepreneurship, and accomplish sustainable environment. The researchers have identified the five key dimensions of Smart City as smart environment, smart economy, smart citizens, smart service, and smart government.

Caragliu et al.(2009) defined Smart City as a city where investments in human and social capital along with traditional(transportation-based) and modern(ICT) communication infrastructure fuel sustainable economic growth, high quality of life, and wise management of natural resources through participatory governance. 
Table 1. The Evolution of U-City Strategy

\begin{tabular}{|c|c|c|}
\hline \multicolumn{2}{|c|}{ Types of U-City Strategy } & Contents \\
\hline \multicolumn{2}{|c|}{ Information-Centered U-City } & Information Project \\
\hline \multicolumn{2}{|c|}{ ICT-Centered U-City } & Sensing, Networking, Interface, Processing, Security and Privacy \\
\hline \multicolumn{2}{|c|}{ Place-Centered U-City } & Building, Facility, Road, District, City \\
\hline \multirow{4}{*}{$\begin{array}{c}\text { Multilayered } \\
\text { U-City }\end{array}$} & Service & Life, Work, Recreation, Mobility \\
\hline & ICT & Sensing, Networking, Interface, Processing, Security and Privacy \\
\hline & Infrastructure & Fixed U-City Infrastructure, Network, Mobile U-City Infrastructure \\
\hline & Management & $\begin{array}{l}\text { Information Management, Facility Management, Administrative } \bullet \text { Financial } \\
\text { Management, Citizen Participation }\end{array}$ \\
\hline
\end{tabular}

Intelligent Community Forum(ICF) defines Intelligent Cities as territories that bring innovation and ICTs within the same locality. ICF (2006) provided five conditions of Intelligent Cities as follows: significant deployment of broadband communities to business, government facilities and residences; effective education, training and workforce capacity to perform knowledge-intensive work; policies and programs that promote digital democracy to ensure that all sectors of the society and citizens benefit from the broadband revolution; innovation in the public and private sectors and efforts to create economic clusters and risk capitals to fund the development of new businesses; and effective economic development marketing that leverages the broadband of the community to attract talented employment and investment.

\subsection{Concept of the U-City}

The word 'ubiquitous' is derived from a Latin root and means 'existing everywhere' regardless of time and place. Recently, the term has come to indicate environment where anyone can freely access to the wireless network regardless of time and place. Under current regulations, the U-City is a city that provides U-City services whenever and wherever needed based on U-City infrastructure built upon technology that is designed to enhance the quality of life. In other words, it is a city where information regarding main functions of the city and related services can be provided upon request using the infrastructure built on the cutting-edge technology. Thus, the U-City is the most technically advanced model of the future city by actively using ICT to improve the quality of life.

As seen above, the U-City is a kind of cities where the infrastructure of the city is managed based on the advanced technology, and it provides services to its residents regardless of place and time. Thus, U-City is the space and place where ICT(technology) -infrastructure(facility) - management service are related intelligently(Shin, 2011). To analyze the evolution of the U-City strategy based on its conceptual characteristics, following classifications are utilized: information-centered U-City, ICT-centered U-City, place -centered U-City, and multilayered U-City(Lee, et al., 2010)(Table 1).

Research and plans concerning U-City tend to be focused more on information-centered U-City and ICT-centered U-City. However, as the concept of UCity has evolved from information-centered U-City and ICT-centered U-City to place-centered U-City and finally to multilayered U-City, the current concept of U-City is considered as the one close to the 'multilayered U-City' where ICT (technology)-infrastructure (facility)-management service is integrated into one system.

\subsection{Concept of the U-City Competitiveness}

Consistent with the definition provided earlier, the U-City is a city that provides necessary services regardless of place and time as all the infrastructure is informatized and managed efficiently based on advanced technology. On the other hand, urban competitiveness refers to the ability of an urban region to produce and market a set of products (goods and services) that represent good value (not necessarily lowest price) in relation to comparable products of other urban regions (Websterand Muller, 2000). The idea that cities are competing with each other to attract and retain a number of functions and 'customers'-e.g. talent, inhabitants, companies, invest- 
ments, visitors(Van den Berg and Braun, 1999; Malecki, 2007) - has been gaining ground in urban practice and planning(Carvalho, 2012). The importance of urban competitiveness has been emphasized as the independence of cities within nations has accelerated and it plays in important role in regional economic prosperity and improving its residents' quality of life.

Thus, the concept of U-City competitiveness, as the fusion of U-City and urban competitiveness means the ability of a city to provide necessary service to its residents immediately upon request and to manage the urban space which maximizes convenience using ICT, U-City infrastructure, service, and management.

\section{Analysis on Future City-Related Index}

As literature review and footing stone of U-City Competitiveness Index Development, we will analyze the existing future city-related indices. Many of future city-related indices have been developed for assessing Smart City. Though the concept of smart city and that of U-City are slightly different, it is still valuable to explore indices related to Smart City as another concept of the future city. We intend to explore the two indices related to Smart City, and an index related to U-City for developing the frame for U-City
Competitiveness Index.

\subsection{Smart Cities Ranking by Vienna University of Technology}

Vienna University of Technology(TU Wien) conducted Smart City related project, the ${ }^{『}$ Smart Cities: Ranking of European medium-sized cities $₫$. TU Wien (2007) defines the components of a Smart City as industry, education, participation and technical infrastructure. The scholars hierarchically organized these components using 6 characteristics, 31 factors, and 74 indicators to rank medium sized European cities(Table 2). The ranking aims to offer a new view on medium-sized cities in Europe which have to cope with competition of the larger metropolises on corresponding issues and their respective differences and comparative advantages and disadvantages based on a comprehensive catalogue of indicators. The ranking provides a city profile for each city based on the standardized information from the z-transformation.

\subsection{Smart City Index by Taipei III}

Smart City Index was developed by Taipei III(Institute for Information Industry) in 2010. The index is composed of 5 dimensions of smart environment, smart economy, smart service, smart citizen, and smart government; 15 pillars, and 39 indicators (Figure 1). The 39 indicators which are more closely

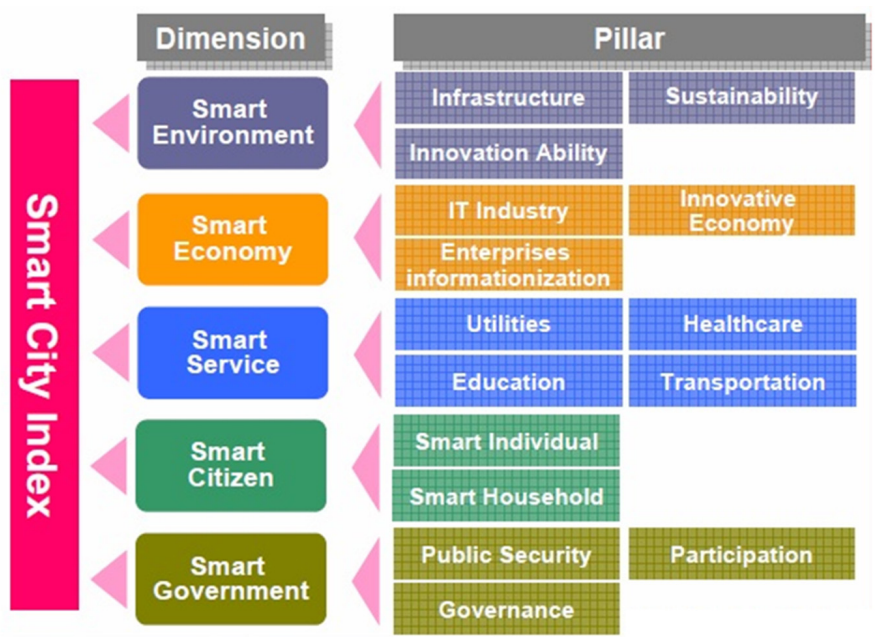

Figure 1. Analysis Structure of Smart City

Resource: FIND-III, CCID, 2010 
Table 2. Factors and Indicators Included in Smart Cities Ranking

\begin{tabular}{|c|c|c|}
\hline Characteristics & Factors & Main indicators \\
\hline \multirow{6}{*}{$\begin{array}{l}\text { Smart } \\
\text { economy }\end{array}$} & Innovative spirit & $\begin{array}{l}\text { R\&D expenditure in percent of GDP, employment rate in knowledge- } \\
\text { intensive sectors etc. }\end{array}$ \\
\hline & Entrepreneurship & Self-employment rate, new business registered \\
\hline & $\begin{array}{c}\text { Economic } \\
\text { image\&trademarks }\end{array}$ & Importance as decision-making center(HQ etc.) \\
\hline & Productivity & GDP per employed person \\
\hline & Flexibility of labor market & Unemployment rate, proportion in part-time employment \\
\hline & $\begin{array}{c}\begin{array}{c}\text { International } \\
\text { embeddedness }\end{array} \\
\end{array}$ & $\begin{array}{l}\text { Companies with HQ in the city quoted on national stock market, air } \\
\text { transport of passengers, etc. }\end{array}$ \\
\hline \multirow{7}{*}{$\begin{array}{l}\text { Smart } \\
\text { people }\end{array}$} & Level of qualification & $\begin{array}{l}\text { Importance as knowledge center(top research centers etc.), foreign language } \\
\text { skills etc. }\end{array}$ \\
\hline & $\begin{array}{l}\text { Affinity to lifelong } \\
\text { learning }\end{array}$ & Book loans per resident, participation in life-long-learning in percent etc. \\
\hline & Social and ethnic plurality & Share of foreigners, share of nationals born abroad \\
\hline & Flexibility & Perception of getting a new job \\
\hline & Creativity & Share of people working in creative industries \\
\hline & $\begin{array}{l}\text { Cosmopolitanism } \\
\text { /open-mindedness }\end{array}$ & $\begin{array}{l}\text { Voters turnout at European elections, immigration-friendly environment } \\
\text { (attitude towards immigration), knowledge about the EU }\end{array}$ \\
\hline & Participation in public life & Voters turnout at city elections, participation in voluntary work \\
\hline \multirow{3}{*}{$\begin{array}{c}\text { Smart } \\
\text { governance }\end{array}$} & $\begin{array}{l}\text { Participation in } \\
\text { decision-making }\end{array}$ & $\begin{array}{l}\text { City representatives per resident, political activity of inhabitants, share of } \\
\text { female city representatives etc. }\end{array}$ \\
\hline & Public and social services & $\begin{array}{l}\text { Expenditure of the municipal per residents in PPS, share of children day } \\
\text { care etc. }\end{array}$ \\
\hline & Transparent governance & $\begin{array}{l}\text { Satisfaction with transparency of bureaucracy, satisfaction with fight against } \\
\text { corruption }\end{array}$ \\
\hline \multirow{4}{*}{$\begin{array}{l}\text { Smart } \\
\text { mobility }\end{array}$} & Local accessibility & Public transport network per inhabitant etc. \\
\hline & (inter-)national accecibility & International accessibility \\
\hline & $\begin{array}{l}\text { Availability of } \\
\text { ICT-infrastructure }\end{array}$ & Computers in households, broadband internet access in households \\
\hline & $\begin{array}{l}\text { Sustainable, innovative } \\
\text { and safe transport systems }\end{array}$ & $\begin{array}{l}\text { Green mobility share(non-motorized individual traffic), traffic safety, use of } \\
\text { economical cars }\end{array}$ \\
\hline \multirow{4}{*}{$\begin{array}{l}\text { Smart } \\
\text { environment }\end{array}$} & $\begin{array}{c}\text { Attractivity of natural } \\
\text { conditions }\end{array}$ & Sunshine hours, green space share \\
\hline & Pollution & Summer smog(Ozone), particulate matter etc. \\
\hline & Environmental protection & Individual efforts on protecting nature, opinion on nature protection \\
\hline & $\begin{array}{c}\text { Sustainable resource } \\
\text { management }\end{array}$ & $\begin{array}{l}\text { Efficient use of water(use per GDP), efficient use of electricity(user per } \\
\text { GDP) }\end{array}$ \\
\hline \multirow{7}{*}{ Smart living } & Cultural facilities & $\begin{array}{l}\text { Cinema attendance per inhabitant, museums visit per inhabitants, theater } \\
\text { attendance per inhabitant }\end{array}$ \\
\hline & Health conditions & Life expectancy, hospital beds per inhabitant, doctors per inhabitant etc. \\
\hline & Individual safety & Crime rate, death rate by assault etc. \\
\hline & Housing quality & $\begin{array}{l}\text { Share of housing fulfilling minimal standards, average living area per } \\
\text { inhabitant etc. }\end{array}$ \\
\hline & Education facilities & Students per inhabitant, satisfaction with access to educational system etc. \\
\hline & Touristic attractivity & Importance as tourist location, overnights per year per resident \\
\hline & Social cohesion & Perception on personal risk of poverty, poverty rate \\
\hline
\end{tabular}

Resource: Giffinger et al., 2007, Smart Cities- Ranking of European medium-sized cities 
Table 3. Indicators Included in the U-City Index

\begin{tabular}{|c|c|c|}
\hline Division & Sub-Division & Indicators \\
\hline \multirow{6}{*}{ ICT } & \multirow{2}{*}{$\begin{array}{c}\text { Infrastructure and } \\
\text { access }\end{array}$} & Fixed-telephone subscriptions per 100 inhabitants \\
\hline & & Percentage of households with a computer \\
\hline & \multirow{2}{*}{ Use } & Percentage of individuals using the Internet \\
\hline & & Number of Internet subscriptions \\
\hline & \multirow{2}{*}{ Skill } & Secondary gross enrollment ratio \\
\hline & & Tertiary gross enrollment ratio \\
\hline \multirow{11}{*}{ Infrastructure } & \multirow{8}{*}{ Intelligent facilities } & Civil affairs administration \\
\hline & & Transportation \\
\hline & & Medical welfare \\
\hline & & Environment \\
\hline & & Crime/disaster prevention \\
\hline & & Education \\
\hline & & Culture \\
\hline & & Work/employment \\
\hline & \multirow{2}{*}{$\begin{array}{c}\text { Communications } \\
\text { network }\end{array}$} & Cable \\
\hline & & Wireless \\
\hline & \multicolumn{2}{|l|}{ Operation center } \\
\hline \multirow{8}{*}{ Service } & \multicolumn{2}{|c|}{ Civil affairs administration } \\
\hline & \multicolumn{2}{|c|}{ Transportation } \\
\hline & \multicolumn{2}{|l|}{ Medical welfare } \\
\hline & \multicolumn{2}{|l|}{ Environment } \\
\hline & \multicolumn{2}{|c|}{ Crime/disaster prevention } \\
\hline & \multicolumn{2}{|c|}{ Education } \\
\hline & \multicolumn{2}{|l|}{ Culture } \\
\hline & \multicolumn{2}{|l|}{ Work/employment } \\
\hline \multirow{2}{*}{ Management } & \multicolumn{2}{|l|}{ Software } \\
\hline & \multicolumn{2}{|l|}{ Hardware } \\
\hline
\end{tabular}

Resource: Shin D.B., 2011, A Study on the Change of Urban Space and the Direction of Urban Planning in the UCity Age

to the Smart City Index were selected among preliminarily-selected 68 indicators. Each of the indicators was used after being normalized and equally weighted as 20 percent for each of the five dimensions. Finally, ranking in each dimension and pillar was calculated. The results were used in ICT application strategy and industrial clusters and urban renewal plans of Taipei City.

\subsection{U-City Index by Shin}

U-City Index was developed by $\operatorname{Shin}(2011)$ to assess the stages of Korean U-City development under the assumption that the lifestyle of people will undergo several changes as U-City age arrived, and thus the structure of urban space will change. U-City Index is composed of four divisions of ICT, infrastructure, service, and management, and 27 indicators as seen in Table 3 . The results were used for quantifying and measuring the stage of U-City development of eight cities in Gyeonggi-do of Korea.

\subsection{Implications for U-City Competitiveness Index}

After careful assessment of Smart Cities Ranking, Smart City Index, and U-City Index, certain definite differences were noted in the scope of evaluation between U-City Index and Smart City-related indices such as Smart Cities Ranking and Smart City Index. There was a focus on evaluating competitiveness of the economy, governance, environment, transport, and people of the Smart City. On the other hand, U-City Index usedfactors that are directly related to U-City such as ICTinfrastructure, services provided through U-City, management of U-City for evaluation. 
Although the evaluation strategy for Smart City provides an adequate structure for assessment of overall competitiveness of the city with consideration of the components of the city, there are difficulties in directly assessing the ICT that plays a central role in the informatization society as well as its infrastructure, service and governance. On the other hand, U-City Index focuses on the level of actualization of the U-City. However, some sections are only assessed based on their operation capabilities and it also lacks in assessment of the developmental potentials as well as plans for investment in U-City infrastructure.

U-City Competitiveness Index serves to evaluatethe ability of a city to provide necessary information to its residents immediately upon request and to manage the urban space which maximizes convenience using ICT, U-City infrastructure, service, and management. Therefore, it is required to have proper structure formation, selection of indices that correctly represent reality and processes of weighted-average calculations. In addition, it is thought that focusing on assessment of U-City competitiveness based on factors such as technology, service, and management would be more appropriate than assessment on widerange analyses.

\section{Plan for Developing U-City Competitiveness Index}

\subsection{Step 1. Preparing an Evaluation System}

The first step in undertaking the U-City Competitiveness Index development process is to prepare an evaluation system. Preparation of an evaluation system refers to the process of analyzing concepts and index structures used in previous research, identifying factors that decide U-City Competitiveness and examining these factors. For instance, the aforementioned main factors for U-City such as ICT, infrastructure, service, and management are each considered as adimension. A pillar exists under each dimension and each pillar completes the structure composed of indicators that are the most direct and detailed.

\subsection{Step 2. Selecting Indicators}

The next step is to choose the indicators which will be used in the assessment. The variability factor is selected based on the indicators with consideration to representability, explainability, and possibility of data collection. With the selected indicators, correlation analysis is conducted to prevent duplications and final indices are then selected.

\subsection{Step 3. Normalization}

At this point, selected indicators should be normalized. There are multiple techniques available for standardization such as $\mathrm{z}$-score and rescaling normalization to allow for comparisons among the indicators. Z-score is usually used for ordinal scales and rescaling normalization technique can be used for interval scales as well (Kim, 2010). Therefore, the indicators are normalized using the re-scaling normalization technique.

\subsection{Step 4. Determination of Weight Value}

The next step is to determine the weight to be given each indicator in U-City Competitiveness Index using AHP (Analytic Hierarchy Process). AHP is one of multi criteria decision making method which can derive relative weight from pairwise comparisons. It is widely used in many practical decisions making and will be useful to determine the weight value for indicators used in the Index. One caveat is that selection of experts should be done carefully as the survey results may be distorted based on incorrect selection of experts.

\subsection{Step 5. Establishment of U-City Competitiveness Index}

Finally, U-City Competitiveness Index is drafted by applying weighted values to the standardized values of each indicator. The following formula illustrates how this is carried out.

$$
\begin{aligned}
U C_{n}= & I C T_{n} \cdot W_{i}+U I_{n} \cdot W_{j}+U S_{n} \cdot W_{k} \\
& +U M_{n} \cdot W_{i}+\cdots \cdots \\
I C T_{n}= & I C T F_{n} \cdot W_{m}+I C T D_{n} \cdot W_{n} \\
& +I C T M_{n} \cdot W_{o}+\cdots \cdots
\end{aligned}
$$




$$
\begin{aligned}
U I_{n}= & I F_{n} \cdot W_{p}+I D_{n} \cdot W_{q}+I M_{n} \cdot W_{r}+\cdots \cdots \\
U S_{n}= & S F_{n} \cdot W_{s}+S D_{n} \cdot W_{t}+S M_{n} \cdot W_{u}+\cdots \cdots \\
U M_{n}= & M F_{n} \cdot W_{v}+M D_{n} \cdot W_{w} \\
& \quad+M M_{n} \cdot W_{x}+\cdots \cdots
\end{aligned}
$$

$U C_{n}$ : U-City Competitiveness index of $\mathrm{n}$ city

$I C T_{n}:$ ICT index of $\mathrm{n}$ city

$U I_{n}$ : U-City infrastructure index of $\mathrm{n}$ city

$U S_{n}:$ U-City service index of $\mathrm{n}$ city

$U M_{n}$ : U-City management index of $\mathrm{n}$ city

$W_{i, j, k \ldots}$ : weight value of each factor

$I C T F_{n}, I C T D_{n}, I C T M_{n}, I F_{n}, I D_{n}$,

$I M_{n}, S F_{n}, S D_{n}, S M_{n}, M F_{n}, M D_{n}, M M_{n}$

: pillar of each dimension

\section{Conclusion}

This study examined the concepts of the future city via literature review as part of preparation for the development of U-City Competitiveness Index. In addition, the steps for development of U-City Competitiveness Index were suggested via analysis on the insights on the existing future-city-related index and U-City Competitiveness Index.

Through this process, U-City has come to mean a city where ICT, infrastructure, and service-management are related and dependent on one another, and U-City Competitiveness refers to the ability of a city to provide necessary information to its residents immediately upon request and to manage the urban space which maximizes convenience using ICT, UCity infrastructure, service, and management. Thus, it is required to have proper structure formation, selection of indices that correctly represent reality and processes of weighted-average calculations. In addition, it is thought that focusing on assessment of UCity competitiveness based on factors such as technology, service, and management would be more appropriate than assessment on wide-range analyses.

Proposed U-City Competitiveness Index development process is as follows: preparation of evaluating system - selecting indicators - normalization - determination of weight value - establishment of formula.
In particular, in selecting indicators, representability, explainability, and possibility of data collection must be considered and correlation analysis should be done to prevent duplications of indicators. In addition, careful selection of experts is needed when surveying experts regarding weighted value determination.

Additional research and discussion are needed to develop U-City Competitiveness Index that is reasonable and agreeable by following the process suggested in this study. Considerations must also be given to the current level of technology and services provided via U-City. The results of this study carrysignificance in that it suggests the framework for development of U-City Competitiveness Index via examination of concepts and related indices and may contribute to the continuous evaluation on the U-City competitiveness in the future.

\section{Acknowledgements}

This study was supported by the U-City Development Project(07첨단도시A01) funded by the Ministry of Land, Transport and Maritime Affairs.

\section{References}

1. Caragliu, A., Del Bo, C. and Nijkamp, P., 2009, Smart Cities in Europe, Proc. of the $3^{\text {rd }}$ Central European Conference in Regional Science.

2. Carvalho, L., 2012, Urban Competitiveness, U-City Strategies and the Development of Technological Niches in Songdo, South Korea, in Melih Bulu(ed.), 2012, City Competitiveness and Improving Urban Subsystems: Technologies and Applications, IGI Global, Hershey, PA, pp.197-216.

3. Giffinger, R., Fertner, C., Kramar, H., Kalasek, R., Pichler-Milanović, N., and Meijers, E., 2007, Smart Cities-Ranking of European Medium-Sized Cities, Center of Regional Science, Vienna University of Technology, pp.5-14, 22-23.

4. Hong, H.J. and Shim, J.H., 2010, Future City via Smart City, National Information Society Agency, pp.3-15.

5. Intelligent Community Forum, 2006, What is an Intelligent Community.

6. Kim, K., Chun, J.Y., Shin, D.B., Lim, S.Y., 2011, 
Research Trends of U-City Theses in Korea and Oversea, Journal of the Korean Society for GeoSpatial Information System, Vol.19, No.1, pp.53-61.

7. KRIHS, 2012, Research Trends on U-City Index, UCity e-Report, Korea Research Institute for Human Settlements, Vol.1, pp.10-19.

8. Lee, S.H. and Leem, Y.T., 2010, Ubiquitous City Strategic Roadmapping Model, Journal of Korea Planners Association, Vol.45, No.6, pp.179-190.

9. Malecki E.J., 2007, Cities and Regions Competing in the Global Economy: Knowledge and Local Development Policies, Environment and Planning C: Government and Policy, Vol.25, pp.638-654.

10. Shin, D.B., 2011, A Study on the Change of Urban Space and the Direction of Urban Planning in the UCity Age, Korea Research Institute for Human
Settlements, pp.13-19, 67-75.

11. Taipei Institute for Information Industry, 2010, Smart City Index \& Development, https://www. intelligentcommunity.org/clientuploads/PDFs/BBE201 0-Workshop-Yueh-III.pdf

12. Van Den Berg, L. and Braun, E., 1999, Urban Competitiveness, Marketing and the Need for Organizing Capacity, Urban Studies, Vol.36, No.5-6, pp.987-999.

13. Webster, D. and Muller, L., 2000, Urban Cometitiveness Assessment in Developing Country Urban Regions: The Road Forward, Towards a Methodology for Conducting City Development Strategies, The World Bank, Washington D.C., pp.142. 